Environmental Research Journal 6 (4): 293-303, 2012

ISSN: 1994-5396

(C) Medwell Journals, 2012

\title{
Government Regulatory System and Compliance with Forestry Policy in South Busoga Forest Reserve, Mayuge District-Uganda
}

\author{
${ }^{1,2}$ A.C. Otieno, ${ }^{2}$ R.A. Kapiyo, ${ }^{2}$ B.O. Oindo and ${ }^{3}$ M. Buyinza \\ ${ }^{1}$ Department of Geography, Faculty of Education, Arts and Vocational Studies, \\ Busoga University, P.O. Box 154, Iganga, Uganda \\ ${ }^{2}$ Department of Environmental Sciences, School of Environment and Earth Sciences, \\ Maseno University, P.O. Box 333, Maseno, Kenya \\ ${ }^{3}$ Department of Community Forestry, Faculty of Forestry and Nature Conservation, \\ Makerere University, P.O. Box 7062, Kampala, Uganda
}

\begin{abstract}
Administrative innuendo exhibited in the Ugandan forestry docket had its genesis from delegitimisation of the policies ostensibly, attributed to conflicts by stakeholders on natural resources, manifested in non-compliance and ineffective enforcement hence, the petering out of the government owned forest reserves in the country. A total of 344 respondents participated from the households within and engulfing South Busoga Central Forest Reserve (SBCFR) and 31 conservationists forming the government regulatory system participated in this research. The study showed that there was a moderate relationship between government regulatory system and the local community's compliance with the UFP in 2001 at 0.422 . The Chi statistic values showed that none of the elements of the government regulatory system was $<9.21$ at $0.01 \mathrm{df}=2$ thus statistically insignificant. It was also found that the elements of government regulatory system were not properly coordinated despite being loosely under NEMA and the local politicians usurped both the powers and authority of NFA in either enforcement of UFP in 2001 hence, rendering NFA officials incompetent. Thus to avoid de-legitimization of the UFP 2001, there was a need to have a positive political will and NFA to reclaim from the politicians its constitutional rights to effectively manage the central forest reserves in the country.
\end{abstract}

Key words: Conflict, de-legitimisation, enforcement, local communities, non-compliance, Kenya

\section{INTRODUCTION}

Uganda was a protectorate of Britain and therefore, shared with Kenya and later on Tanganyika colonial regulations on natural resources. Forestry in Uganda started in 1899 with the creation of the Botanical and Agricultural Department. In 1917, the botanical and scientific sections were handed over to Agricultural Department and Forestry became the responsibility of the Forestry Department (FD) (Olet, 1977; Hamilton, 1984). The establishment of forest department was in line with the East African Forestry Regulations published in 1892 which transferred management mandate to the FD. The regulations were to curtail forest destruction by shifting cultivators and pastoral communities (Mwangi, 1998). A number of researchers also claimed that the rules provided for the gazettement or de-gazettement of forests; outlined forest offences and their penalties, introduced the compounding of offences; authorized the issue of licenses for permitted activities (Mwangi, 1998; Hamilton, 1984; Otieno, 2003; Otieno and Buyinza, 2010). These therefore, pushed the local communities living adjacent the forest reserve out of them and outlawed their customary laws.

Initially in Uganda, the forests were state controlled through various agreements between protectorate government under Britain and the native authorities as negotiated at the time. These included among others; Uganda Memorandum of Agreement (Forest) 1907 and the Forest Ordinance (1913) following, the Toro Agreement in 1900, Ankole Agreement in 1909 (Hamilton, 1984; Olet, 1977; Mupada, 1997). Olet (1977) added that by 1910 sound foundations had been laid and the way lay open for the creation and development of a permanent forest estate. There was much concentration on exploiting the forests, establishment ornamental trees on a number of plantations and species trial projects between the periods of 1910-1929. All these agreements were quazi-legal and

Corresponding Author: A.C. Otieno, Department of Geography, Faculty of Education, Arts and Vocational Studies, Busoga University, P.O. Box 154, Iganga, Uganda 
without effective consultations with the local communities living adjacent the forest reserves, leave alone the exploitation by the FD at the expense of the natives. This therefore, became a point of conflict in natural resource management.

In Uganda forest policies owe their origins from the 1929 Nicholson report which recognized the vital role that forests and trees play in the environment and created the need for delimiting and defining forest boundaries (Mugyenyi et al., 2005). Subsequent policies such as 1948, 1970, 1988 and currently 2001 oscillated between environmental benefits and production of goods for economic benefit. Olet (1977) added that between 1930 and 1949 many areas were reserved, working plans for forest reserves were drawn up and in 1968 and the Local Government Forest Reserves were amalgamated with the Central Government Forests. In these apparently no consultations were made to the local communities torching the forest reserves. The rigid forest management strategies were imposed by the colonial government which rubbished the traditional African forest conservation strategies (Banana et al., 2007). This seemingly was the origin of non-compliance leading to enforcement of forest polices on communities who prior had a mutual relationship with the biosphere in their proximity.

Uganda like any other independent state inherited, the system of state ownership of all natural resources, continuing the colonial tradition. In this case, the state squanders the resources by allocating projects which people viewed as benefiting the state, especially people in government (Loefler, 2000). In essence prior to 1995 , Uganda went through a series of historical episodes that have been characterized by different forms of legislative representation or non-representation at all (Tumushabe and Bainomugisha, 2004). This therefore meant that there was no proper legislation on environmental issues apart from ruling by decrees which disregarded the opinion of the future complaints. This has ended up in de-legitimization of the policies hence, conflicts between the state agencies and the community living adjacent the resources manifested in the events at SBCFR, Mayuge district.

The Uganda Forestry Policy 2001's (UFP in 2001) roots can be traced from the National Environment Action Plan (NEAP) launched in August, 1991 and started working in November 1991 (Aryamanya-Mugisha, 1991). NEAP was to be time bound; actions oriented and use participatory process in providing a broad framework for integrating environment issues into the overall national socio-economic development plan. Thus was to be multi-sectoral in all organs of the society, both public and private. The UFP in 2001 emphasized the following in connection to the management of Central Forest Reserves (CFRs) in the country; the permanent forest estate under the government; profitable and productive forestry plantation business; Collaborative Forest Management (CFM) and water shed protection forests. It also indirectly impacts on CFRs through; the development and sustainable management of natural forests on private land and encouragement of tree-growing on farms (Republic of Uganda, 2001, 2002, 2003).

A legal framework was attained by enacting the National Forestry and Tree Planting Act (NFTPA) 2003 to replace the Forest Act in 1964 (Republic of Uganda, 2001, 2003). The Act reviewed, the National Environment Statute in 1995, the Wildlife Statute in 1996, the Water Statute in 1995, the Local Government Act in 1997 Land Act in 1998 and others in order to harmonize them (Republic of Uganda, 2001). The policy emphasized a common management authority for the sectoral institutions concerned with the biodiversity conservation. Thus, National Forestry Authority (NFA) had to develop close links with NEMA, UWA, relevant line ministries, $\mathrm{NGOs} / \mathrm{CBO}$ and the private sector (Republic of Uganda, 2001). This was ideal but in reality especially in the district forestry services there was a growing envy skewed towards NFA believed to be better financed hence, left to battle its own deforestation challenges alone. The study had the following objectives; to assess the efficacy of the UFP in 2001 in curbing deforestation of SBCFR; to assess how National Forest Authority was enforcing the UFP in 2001 in SBCFR and to determine the relationship between government regulatory system and local communities' compliance with the UFP in 2001 in SBCFR.

Description of the study area: The case study forest reserve was gazatted and demarcated in Legal Notice No. 110 of 1938. Under Legal Notice No. 41 of 1948 the title of the forest is South Busoga Central Forest Reserve. It is currently under NFA with a total area of 16382 ha. It is absolutely situated on the northern shores of L. Victoria between latitudes $0^{\circ} 16^{\prime} 59^{\prime \prime} \mathrm{N}$ and longitudes $33^{\circ} 34^{\prime} 22^{\prime \prime} \mathrm{E}$ (Davenport et al., 1996). The area has a bimodal type of rainfall which begins in March or April with peaks in May to June and October to November. From December to March the area experiences dry spell though occasionally irregular rains fall in the former months (Davenport et al., 1996).

The natural vegetation conforms to the rainfall intensity thus decreases eastwards and southwards from Kityerera. According to Davenport et al. (1996) the forest can be broadly classified as medium altitude moist semi-deciduous forest (Albizia-Chlorophora dominated) 
and moist Combretum savanna this is within an attitudinal range of 1140-1300 $\mathrm{m}$ above sea level. The lake shore vegetation in the reserve is of average conservation value, especially the papyrus swamp. The main species in the closed area were Albizia-Markhamia with Chlorophora Canarium, Croton macrostachys, Sapium, Premna and Pseudospondias, over an under storey mainly of Caetacme, Teclea and Clausena over a dominantly Aframomum and Cyathula achyranthoides. Besides these between 1949-1941 Mvule (Chlorophora excelsa) and other valuable species were planted in 765 acres. Most of this vegetation has been devegetated due to de-legitimization of the forestry policy through encroachments leaving behind tree stamps of the mentioned species.

\section{MATERIALS AND METHODS}

This was a case study conducted through a crosssectional survey research design. It was concerned with determining the relationship between government regulatory system and local communities' compliance with the UFP in 2001 in SBCFR. It specifically investigated the relationship between non-compliance and enforcement of Uganda Forest Policy in 2001 in SBCFR. Such issues are appropriately investigated using a cross-sectional survey research design. The design enabled the researchers to obtain information that described existing phenomena with respect to one or more variables (Mugenda and Mugenda, 2003). Given its nature as viewed by many researchers including the researchers, triangulation was used especially QUAL-Quan Model where qualitative study came before a quantitative study as arranged in the objectives/ research questions of the research (Gay et al., 2009; Bailey, 2007; Amin, 2005; Morse and Richards, 2002; Nachmias and Nachmias, 1987). A total of 344 respondents participate out of the expected 369 households. This number especially of the households was chosen in line with Krejcies and Morgan's sampling size for research activities determination table (Amin, 2005). There was also triangulation of sampling techniques thus both probability and non-probability sampling techniques were concurrently used (Bailey, 2007; Amin, 2005). The techniques applied were stratified sampling; snowballing, purposive sampling and convenience sampling techniques.

The researchers used; questionnaires, interviews, observation and document analysis as the main tools for collecting data. The researchers were mainly concerned with views, perceptions, opinions, attitudes and behaviors of the respondents. Such information could be best collected using the given tools (Bell, 1999;
Cauvery et al., 2007; Oso and Onen, 2005). The percentage distribution techniques was used to show the particular frequencies of respondents preferring a particular alternative to give the face value implications on non-compliance and enforcement problems of the policy on deforestation of SBCFR. Statistical Package for the Social Sciences Version 10 (SPSS) was used given the number of respondents and carrying out cross tabulations which cannot be done either manually or using Excel (Fisher, 2007; Fraenkel and Wallen, 2008). A Spearman correlation analysis was done to establish the relationship between government regulatory system and the local community engulfing the SBCFR's compliance with the forest policy. The $\chi^{2}$-test for goodness of fit was used to analyze the frequencies in line with the research questions (Kothari, 2004; Oso and Onen, 2005).

\section{RESULTS AND DISCUSSION}

Several questions were asked to both the lead agencies and the local community engulfing the forest reserve which sought their opinion, views and attitudes towards the UFP in 2001 besides other environmental policies closely related to the forestry policy. Data collected were presented, analysed and discussed in the following subsections.

The efficacy of the Uganda Forestry Policy in 2001 in curbing deforestation of South Busoga Central Forest Reserve, Mayuge District: The current forestry policy in Uganda is apparently the best since time immemorial in the country given its inclusivity of all stakeholders both at its making and implementation. It was perceived as in Table 1 .

Table 1 shows the main attributes of the local communities engulfing SBCFR, Mayuge district in relation to compliance with the forestry policy viz., gender, age, educational background, occupation and media used to sensitize them and their opinion on important aspects the forestry policy. Male $(60 \%)$ dominate in management of the households as portrayed in Table 1 given the patriarchal nature of the Soga culture from where the research was carried out. The 38.4 mean ages of the respondents authenticated the responses for they were above 18 years an age of consent in the Ugandan Constitution (The Republic of Uganda, 1995). Going by the mean age most of the respondents were within the active working age group hence, their active interaction with the forest reserve at their proximity.

The respondents' education level according to Table 1 shown that $>90 \%$ of them acquired formal education that is from elementary to post secondary level. 
Table 1: Attributes of the local communities relevant to compliance with the Forestry Policy at South Busoga Central Forest Reserve, Mayuge district $(\mathrm{n}=344)$

\begin{tabular}{|c|c|c|}
\hline \multirow[b]{2}{*}{ Characteristics } & \multicolumn{2}{|c|}{ Local communities' responses } \\
\hline & $\mathrm{n}$ & Percentage \\
\hline \multicolumn{3}{|l|}{ Gender } \\
\hline Male & 207.0 & 60.0 \\
\hline Female & 137.0 & 40.0 \\
\hline Mean age & 38.4 & - \\
\hline \multicolumn{3}{|l|}{ Educational background } \\
\hline No & 30.0 & 8.7 \\
\hline Basic & 84.0 & 24.4 \\
\hline Secondary & 99.0 & 28.7 \\
\hline Post secondary & 130.0 & 41.4 \\
\hline \multicolumn{3}{|l|}{ Occupation } \\
\hline Peasants & 88.0 & 25.5 \\
\hline Casual & 14.0 & 4.1 \\
\hline Idle & 21.0 & 6.1 \\
\hline NGO & 14.0 & 4.1 \\
\hline Politicians & 76.0 & 22.0 \\
\hline Self employed & 59.0 & 17.1 \\
\hline Govemment employees & 72.0 & 20.9 \\
\hline \multicolumn{3}{|l|}{ Sensitization media } \\
\hline Radio & 225.0 & 65.2 \\
\hline Newspapers & 120.0 & 34.8 \\
\hline Conservationists & 121.0 & 35.2 \\
\hline Village meetings & 112.0 & 32.6 \\
\hline Television & 58.0 & 16.9 \\
\hline All the medias given & 28.0 & 8.1 \\
\hline No idea & 37.0 & 10.8 \\
\hline \multicolumn{3}{|l|}{ Aspects of the policy } \\
\hline Collaborative forest management & 143.0 & 41.6 \\
\hline Privatisation of the forest reserve & 193.0 & 56.1 \\
\hline Transparency in decision making & 99.0 & 28.8 \\
\hline Sharing of the forest resources & 132.0 & 38.4 \\
\hline Campaigns to grow trees & 214.0 & 62.2 \\
\hline Compliance with the forestry policy & 167.0 & 48.5 \\
\hline
\end{tabular}

Basic education which include, elementary and primary level formed less than a quarter of the respondents were basically unskilled and at most semi skilled hence had limited choices of work due to lack of skills. Thus, needed a lot of sensitization and enforcement so as to comply with stringent policies. At post primary levels who were $70.1 \%$ there is more integration of skill training enabling individuals to make sustainable choices depending on their abilities, interests, sensitization and enforcements. The post primary level included O Level, A Level, Certificate Course, Diploma, Degrees and Post Graduate courses. Surprisingly, with an $8.7 \%$ of illiterates as per Table 1 the respondents out weighed the national survey which had up to $20 \%$ of the population 15 years and above having no formal education (UBOS in 2006 cited in NEMA). NEMA continued to assert that literate individuals are better equipped to participate in both personal and community development hence, more likely to play part in environmental decision making and to take advantage of opportunities for environmental justice. Given the circumstances at SBCFR, the literacy opportunity had not been exploited by all stakeholders in the forestry resource utilization portrayed by the dwindling of the resources.
Slightly more than quarters $(25.5 \%)$ of the respondents were directly engaged in peasantry farming according to Table 1 . About $>5$ th $(20.9 \%)$ of the respondents were government employees, $6.1 \%$ were idle; $4.1 \%$ casual labours in various activities including farming while $22 \%$ were politicians. All these as per the interview and observation partly and fully participated in farming in the forest reserve. These further included self employed $17.1 \%$ and non-governmental organizations' employees $4.1 \%$. The respondents' participation on farming whether by proxy or directly was a manifestation of the ill definition of property rights over the forest areas in Uganda hence, most people treat them as open access commons. The disappearance of ungazetted forests country wide in Uganda attests to this notion and ostensibly extrapolated in CFRs exemplified with deforestation of SBCFR with impunity (Bikaako-Kajura, 2002).

From Table 1, it was crystal clear that majority $(65.2 \%)$ of the household respondents were sensitised by radio about the Uganda Forestry Policy in 2001. This was due to the mobility or flexibility of radios and often use of traditional or local languages to overcome the literacy barriers that affect the print media. Kiyingi reported that much of NFAs' mentions over the radio and television were aired during prime news times for most people/listeners target news segments. The prime news times in Uganda were at $7.00 \mathrm{am}, 1.00,7.00$ and $9.00 \mathrm{pm}$. Besides, radio programmes were spot announcements that were taped played and repeated at scheduled intervals in addition to the negative publicity by the local politicians in audience participation programmes (Zziwa and Waisswa, 2007). However, television solicited the least response (16.8\%) apparently due to its being expensive, immobility, inflexibility and locally viewed as a good of ostentation. Besides the given televisions were more associated with electricity and urbanization given the low signal coverage in the rural areas of Uganda.

More than a third of the respondents (35.1\%) claimed to have got the Forestry Policy in 2001, through forest and environmental officers referred to as conservationists in Table 1. The apparently low sensitization by the conservationist echoed the sour relationship expressed by many researchers (Nsita, 2006; Tenywa, 2007; Temmerman, 2007; Nsangi, 2006; Natusiimira, 2007). Amidst the uncomfortable relationship appreciation the conservationists' sensitization by more than a third of the households was a panacea towards a collaborative forest management a pinnacle of the Forestry Policy (NFA, 2005). This showed a commitment on the side of the conservationists, especially sensitizations of the forestry policy at SBCFR, Mayuge district. 
With about the similar response on sensitisation by conservationists the household respondents claiming to have read about the Forestry Policy in 2001 through the newspapers were $(34.8 \%)$ as per Table 1 . According to Kiyingi articles published in the local dailies such as New Vision, Bukedde and The Daily Monitor featured issues on evictions, encroachments, concerns about environmental degradation, over harvesting of forest resources, trees planting, timber dealing, timber auction and establishment. Despite the given contribution on awareness, this apparently had the following predicaments hence could not compete with radios; circulation and congested content where they could include among others; politics, leisure, religious issues, advertisements and the next (NEMA, 1999). Above all literacy and ability to purchase them could have curtailed their usage in the remote SBCFR, Mayuge district.

Generally, sensitization of the Forestry Policy in 2001 had been successful among the households living adjacent SBCFR, Mayuge district depicted by merely (10.8\%) being ignorant (Table 1). The same table showed that the policy was sensitized through these medias; radio, newspapers, conservation officers, local council meetings and television this was positively in line with the United Nations declaration of the Decade of Education for Sustainable Development in 2005-2014 endorsed by the 2002 Johannesburg World Summit on Sustainable Development (NEMA, 2004/5). Contradictorily, despite the overwhelming acknowledgement $(81.2 \%)$ of sensitization of the Forestry Policy in 2001 as viewed in Table 1, the degradation of SBCFR negated the expectation of sensitization of the policy. Thus, delegitimization of the policy seemed strong on the push to deforestation of SBCFR, Mayuge district.

From Table1, it was clear that about two thirds of the respondents $(62.2 \%)$ agreed that promotional campaigns to grow trees both within and outside the forest reserve have been effectively done. This could be attributed to the establishment of NFA under Section 52 (1) of the NFTPA, 2003 charged with the management of forestry in the CFRs in Uganda (Republic of Uganda, 2003). Associated to tree planting was privatisation of the forest reserve where more than half the respondents (56.1) agreed to in SBCFR. Kakira Sugar Works and Nile Ply Companies started establishing communal timber plantations in SBCFR despite reported challenges (De Temmerman, 2007). Planted trees dominated the natural vegetation if any in a transect of the forest reserve. This was also clear of planted forest on private lands in the neighbourhood of SBCFR. This was in concomitant with the Forestry Policy in 2001 in the area (Republic of Uganda, 2001).
Collaborative Forest Management (CFM) embraced in other forest reserves such as Mt. Elgon National Park, WBFR, Budongo Forest Reserve and Mabira Forest Reserve was not in SBCFR as seen by less than half (41.6\%) the households' responses in Table 1 (Otieno and Buyinza, 2010; Otieno, 2003; Buyinza, 2010). Only 46.3\% of the lead agents were satisfied with CFM and its application at SBCFR thus needing much input to that effect. From the lead agents it was clear that they gave in to the general view of CFM in Uganda. CFM is done by agreement between the NFA and the local communities willing co-manage a forest reserve in their proximity (NFA, 2003). This had not been done by the time of this research instead there was evidence of privatisation in SBCFR, Mayuge district.

Nearly half the local communities (48.5\%) agreed that the Forestry Policy in 2001 was effective contrary to the observable non-compliance with it in illegal activities carried in the forest reserve (Table 1). Observably as part of the policy, the following were evident; NFA officials posted to the area; sensitization of the policy; planting of the trees in and outside SBCFR; privatization of parts of SBCFR and SBCFR boundaries known by the local populace. On the contrary, there was dismal response on transparency in decision making and equitable sharing of forest resources main pillars of CFM a cardinal aspect of the Forestry Policy in 2001 (Otieno and Buyinza, 2010).

National Forestry Authority and the management of SBCFR, Mayuge district: The Forest Act of 1964 retained the colonial administration approach of the forestry management. Under the 1967 constitution, forest resources were centralized and management vested in the Forest Department (FD) (Mugyenyi et al., 2005). The NFTPA replaced the FD with an autonomous body the National Forestry Authority (NFA). According to the NFA (2005), the organization manages Forestry Department activities in 506 Central Forest Reserves (CFR) in the country. It does this in partnership with the private sector such as companies, firms, nongovernmental organisations; community based organizations and individuals, the central government and Local Government (LGs) in accordance with the NFTPA. Thus, legally NFA is a corporate body with an official seal and may for the discharge of its functions among others in reference to this research sue or be sued (Act No. 52.2b of NFTPA, 2003). NFA's management of SBCFR was as in Table 2 and 3 .

Table 2 shows clearly, that the NFA officials did not evaluate the community's compliance with the Uganda Forestry Policy in 2001 by more than two thirds of their numbers $(67.7 \%)$. Ostensibly, the cardinal aim of NFA as 
Table 2: NFA officials supervision of SBCFR, Mayuge district $(n=31)$

\begin{tabular}{|c|c|c|c|c|}
\hline \multirow[b]{2}{*}{ Activity } & \multicolumn{4}{|l|}{ Response } \\
\hline & Frequently & Occasionally & Never & Rarely \\
\hline Police the forest reserve & $11(35.5 \%)$ & $02(06.5 \%)$ & $17(54.8 \%)$ & $01(03.2 \%)$ \\
\hline Review performance against targets and objectives of the organization & $11(35.5 \%)$ & $03(09.7 \%)$ & $13(41.9 \%)$ & $04(12.9 \%)$ \\
\hline Evaluate the community's compliance with the Uganda Forestry Policy 2001 & $05(16.1 \%)$ & $01(03.2 \%)$ & $21(67.7 \%)$ & $04(12.9 \%)$ \\
\hline Sensitize the local community living adjacent SBCFR on conservation & $10(32.3 \%)$ & $03(09.7 \%)$ & $16(51.6 \%)$ & $02(06.5 \%)$ \\
\hline Do advisory services to the local community & $06(19.4 \%)$ & $05(16.1 \%)$ & $18(58.1 \%)$ & $02(06.5 \%)$ \\
\hline Conflict on conservation with the local community & $16(51.6 \%)$ & $02(06.5 \%)$ & $11(35.5 \%)$ & $02(06.5 \%)$ \\
\hline Conflict on conservation with the local politicians on evictions & $18(58.1 \%)$ & $02(06.5 \%)$ & $09(29.0 \%)$ & $02(06.5 \%)$ \\
\hline
\end{tabular}

Table 3: The mode of eviction at SBCFR, Mayuge district $(\mathrm{n}=344)$

\begin{tabular}{lrr} 
& Response of the local communities \\
Mode of eviction & \multicolumn{1}{c}{ True } & \multicolumn{1}{c}{ False } \\
\hline Notices of evictions given in advance & $198(57.6 \%)$ & $146(42.4 \%)$ \\
Abrupt evictions carried out & $216(62.8 \%)$ & $128(37.2 \%)$ \\
Evictions done by NFA and police & $47(71.8 \%)$ & $97(28.2 \%)$ \\
Prior consultations done with evictees before evictions & $138(40.1 \%)$ & $206(59.9 \%)$ \\
Compensation arrangements done prior to evictions & $102(29.7 \%)$ & $24270.3 \%)$ \\
The evictees resettled & $118(34.3 \%)$ & $226(65.7 \%)$ \\
The encroachers imprisoned occasionally & $227(66.0 \%)$ & $117(34.0 \%)$ \\
The evictees incurred heavy losses of domestic properties during evictions & $240(69.8 \%)$ & $104(30.2 \%)$ \\
Evictions done by NFA and the Local Council officials & $180(52.3 \%)$ & $164(47.7 \%)$ \\
\end{tabular}

an organization is conservation of forest reserves in Uganda. This can be achieved by compliance with the policy. Thus, the act of NFA contradicts Bowman and Asch (1992) who claimed that employees are judged purely in achievement of quantifiable objectives. So, failure to evaluate community's compliance was a predicament on the work schedule of the NFA officials at SBCFR, Mayuge district. This apparently gave room for the local communities living adjacent to the forest reserve to practice illegalities in SBCFR with impunity.

It was also clear that more than half the lead agencies (58.1\%) accepted that no advisory services were rendered to the local community (Table 2). This was contrary to policy statement 10 ; on education, training and research which lays emphasis on; building public awareness of issues in the forest sector and developing promotional campaigns to encourage tree growing (Republic of Uganda, 2001). On the same note, there was thwarting of sensitization of the local community living adjacent to SBCFR by $(51.6 \%)$ of lead agencies' responses. This was a challenge to the NFA officials, hence a set back to compliance with the Uganda Forestry Policy in 2001 as experienced at SBCFR.

More than half $(54.8 \%)$ of the lead agencies agreed that there was no effective supervision of SBCFR, Mayuge district according to Table 2. Slightly above a third of their number $(35.5 \%)$ claimed that policing the forest reserve was efficient and therefore frequent. Only $6.5 \%$ claimed that it was occasional. Supervision is very cardinal in monitoring and evaluating of the services of NFA and its failure was a challenge to implementing the Forestry Policy in 2001 (Republic of Uganda, 2001;
MWLE, 2003). The failure here could be partly attributed to ill-equipment and general inadequate financing of the sector like others in Uganda.

There was open conflict on conservation with the local politicians on evictees accepted to be frequent by $58.1 \%$ of the lead agencies' responses as per Table 2 . Much as less than a third of them $(29 \%)$ claimed that there was no conflict, yet through observation and interview it was quite evident. Through this, conflict on conservation with the local community was also evidently frequent accepted by $51.6 \%$ though denied by $35.5 \%$ (Table 2 ). This therefore could not make the following possible; evaluation of the community's compliance with the Uganda Forestry Policy in 2001, review performance against targets and objectives of the organization effective for it was denied by almost half the population (41.9\%) of the lead agencies' responses and consequently advisory roles to the community failed as in Table 2 . All these testified failure by NFA at SBCFR in Mayuge district.

Many of the households' respondents (71.8\%) conceded that the evictions, especially forceful evictions were carried out by the NFA officials and the police officers (Table 3). Besides more than half of the house holds (52.3\%) agreed that the Local Council (LC) officials could also be present in the process of evictions. The LC officials, involvement's low responses could be attributed to the evictees being voters. From interviews, it was crystal clear that the LCs being part and parcel of the local communities in the proximity of the forest reserve were involved in the illegalities in SBCFR either directly or by proxy. But all in all presence of government officials or their representatives during an eviction authenticated the process. 
The results shown in Table 3 shows that more than two thirds $(70.3 \%)$ of the households' respondents claimed that there was no provision for compensation and slightly less than two thirds $(65.7 \%)$ denounced availability of resettlement opportunities. Through interviews with NFA officials there was a claim that the encroachers had where they came from and thus not homeless as per say. This acted contrary to Article 11 (i) of the International Covenant on Economic, Social and Cultural Rights (ICESCR) and the African Commission on Human and Peoples Rights, determining that the right to housing is part of the African Charter (Anonymous, 2007).

Table 3 also shows that there was a claim that the evictees incurred heavy losses of domestic properties during evictions by $69.8 \%$ of the households' respondents. Interviews had it that what was lost included among others food crops; household utensils; construction materials; clothes and some even claimed money lost. Yet no compensation but the encroachers were occasionally imprisoned as claimed by two thirds $(66.0 \%)$ of the households' respondents (Table 3 ). Thus, the loss of domestic properties, especially uprooting crops from the gardens of the encroachers, imprisonment of culprits are taboos in the Soga culture, the dominant community engulfing SBCFR according to the interviewed hence, soured the relationship between the law enforcers and expected complaints at SBCFR, Mayuge district.

Many of the households' respondents claimed that the evictions were carried out abruptly $(62.8 \%)$ as in Table 3. Contradictorily, more than half $(57.6 \%)$ of the households' respondents, admitted that notices were often given before evictions (Table 3 ). The abruptness of evictions could be attributed to the mode of notification and mostly to the lack of an opportunity for genuine consultations with these evictees viewed by $59.9 \%$ of the households' respondents. The lead agencies' interviewed claimed that consultations were regularly done. A deduction from the two opposite views showed that the consultations if any were not effective thus qualifying evictions to be abrupt with its domestic loss consequences amongst the culprits.
The relationship between government regulatory system and local communities' compliance with the UFP 2001 in SBCFR, Mayuge district: The researchers took the government regulatory system to include the following elements in ensuring conservation of SBCFR, Mayuge district; laws and acts viz., the 1995 Constitution of the Republic of Uganda (The Constitution), The National Forestry and Tree Planting Act NFTPA in 2003, the Uganda Forestry Policy in 2001 UFP in 200, the National Environment Act (NEA), Uganda Wildlife Act (UWA), Local Government Act (LGA), The Police Act, the Leadership Act and enforcement officers viz. Uganda Wildlife Authority (UWA), National Environment Management Authority (NEMA), National Forestry Authority (NFA), Uganda Police Force (Police), District Forestry Services (DFS), District Local Council (DLC), Internal Security Organisation (ISO) and Uganda Peoples' Defense Forces (UPDF). These were tested as in Table 4 and 5.

The results from Table 4 clearly show that even NFA the lead agency in forestry does not satisfy the local communities living adjacent SBCFR, Mayuge district. NFA was statistically insignificant as per the table $\left(\chi^{2}\right.$-calculated $=54.6>\chi^{2}$-tabulated $\left.=9.21\right)$. Despite the statistical results, NFA's work compared to other lead agencies was acknowledged by $60.1 \%$ (Table 4). The acknowledgement could have been attributed to their presence at SBCFR compared to the rest. The statistical

Table 4: Summary of Chi-square statistic value of the enforcement activities of the lead agencies on environmental policies in SBCFR, Mayuge district $(n=344)$

\begin{tabular}{lcccc}
\hline & Local communities' satisfaction \\
& - & \multicolumn{4}{c}{$\begin{array}{c}\chi^{2}- \\
\text { Lead agency }\end{array}$} & $\begin{array}{c}\chi^{2} \text { - } \\
\text { tabulated }\end{array}$ \\
\hline Uganda Wildlife Authority & 182 & 334 & 76.3 & 9.21 \\
National Environment & 194 & 344 & 65.4 & 9.21 \\
Management Authority & & & & \\
National Forestry Authority & 207 & 344 & 54.6 & 9.21 \\
Uganda Police Force & 158 & 344 & 100.6 & 9.21 \\
District Forestry Services & 162 & 344 & 96.3 & 9.21 \\
District Local Council & 167 & 344 & 91.1 & 9.21 \\
Internal Security Organisation & 143 & 344 & 117.4 & 9.21 \\
Uganda Peoples' Defense Forces & 124 & 344 & 140.7 & 9.21 \\
\hline df=2 at 0.01 = 9.210 & & & &
\end{tabular}
$\mathrm{df}=2$ at $0.01=9.210$

Table 5: A correlation observation of lead agencies' enforcement and compliance with Environmental/Forestry laws/Acts at SBCFR, Mayuge district

\begin{tabular}{|c|c|c|c|c|c|c|}
\hline \multirow[b]{2}{*}{ Subjects } & \multicolumn{2}{|c|}{ Enforcement by lead agencies } & \multicolumn{2}{|c|}{ Compliance with environmental/forestry/laws/acts } & \multirow[b]{2}{*}{$\mathrm{d}$} & \multirow[b]{2}{*}{$d^{2}$} \\
\hline & Lead agency & Rank & Law/Act & Rank & & \\
\hline 1 & UWA 182 & 3 & UWA 139 & 6.0 & -3.0 & 9.00 \\
\hline 2 & NEMA 194 & 2 & NEA 161 & 2.5 & -0.5 & 0.25 \\
\hline 3 & NFA 207 & 1 & UFP 161 & 2.5 & -1.5 & 2.25 \\
\hline 4 & Police 158 & 6 & Police Act 126 & 8.0 & 2.0 & 4.00 \\
\hline 5 & DFS 162 & 5 & NFTPA 185 & 1.0 & 4.0 & 16.00 \\
\hline 6 & DLC 167 & 4 & Local Gov’t Act 140 & 5.0 & -1.0 & 1.00 \\
\hline 7 & ISO 143 & 7 & Leadership Act 127 & 7.0 & 0.0 & 0.00 \\
\hline$\underline{8}$ & UPDF 124 & 8 & The Constitution 147 & 4.0 & 4.0 & 16.00 \\
\hline
\end{tabular}


insignificance was attributed to the bitter relations that existed between NFA and the local communities on conservation of the forest reserve, orchestrated by conflict of interest manifested in physical confrontations in the area (Mugyenyi et al., 2005; Nsangi, 2006; Natusiimira, 2007).

Table 4 also shows that other organisations in the environment docket were also insignificant statistically viz., DFS $\left(\chi^{2}\right.$-calculated $=96.3>\chi^{2}$-tabulated $\left.=9.21\right)$, UWA $\left(\chi^{2}\right.$-calculated $=76.3>\chi^{2}$-tabulated $\left.=9.21\right)$ and NEMA $\left(\chi^{2}\right.$-calculated $=65.4>\chi^{2}$-tabulated $\left.=9.21\right)$. The results showed a contradiction in the Environmental Regulation and Enforcement Team (ERET) in Uganda which meets bi-monthly. ERET is responsible for ensuring well co-coordinated and integrated development and implementation of environmental impact assessment and audit monitoring in the country (NEMA, 2004/5). DFS like most civil service sectors in Uganda was ill equipped to effectively aid NFA in enforcement of Forestry Policy in SBCFR, Mayuge district as per the interviews carried out. Thus a relatively dismal performance $\left(\chi^{2}\right.$-calculated $=96.3>\chi^{2}$-tabulated $\left.=9.21\right)$. NEMA and UWA were semi-autonomous bodies with sufficient financing compared to DFS yet failed to assist NFA as per ERET (Table 4).

The DLC also performed dismally $\left(\chi^{2}\right.$-calculated $=$ 91.1> $\chi^{2}$-tabulated $=9.21$ ) as revealed by the results in Table 4. The DLC is both administrative and political head of a district according to the decentralization and leadership hierarchy in Uganda, respectively (Nsita, 2006; Banana et al., 2007). Banana et al. (2007) added that the DLC crafted by-laws and had forestry policy enforcement in their juris diction. But events in SBCFR, Mayuge district did not reflect the forestry policy enforcement as the politicians instigated the local communities against the NFA, viewed as anti-development in the area (Mugyenyi et al., 2005; Nsangi, 2006; Natusiimira, 2007). Despite the support the DLC gave, the local communities engulfing SBCFR on illegalities, they were not given overwhelming acknowledgement of their role in enforcement of forestry policy possibly due to enlightenment of the local communities.

Table 4 portray results indicating the insignificance of security forces in enforcement of forestry policy at SBCFR, Mayuge district as follows UPDF $\left(\chi^{2}\right.$-calculated $=140.7>\chi^{2}$-tabulated $\left.=9.21\right)$; ISO $\left(\chi^{2}\right.$ - calculated $=117.4>\chi^{2}$-tabulated $\left.=9.21\right)$ and Police $\left(\chi^{2}\right.$-calculated $=100.6>\chi^{2}$-tabulated $\left.=9.21\right)$. UPDF could not yield much satisfaction for it is engaged on external insecurity likely to affect the country or flashing out guerilla war fare in the forests (Otieno, 2003; Mugyenyi et al., 2005). ISO was not also exposed to the local communities living adjacent to SBCFR, Mayuge district. Thus, dismal satisfaction as exhibited by the statistic value posted against it (Table 4). The police force therefore, remained the only formidable force to ensure enforcement of environmental/forest crimes in unison with the other lead agencies such as NFA, UWA and NEMA. Table 4 shows a statistically insignificant satisfaction of their work on enforcement of forestry policy at SBCFR by the local communities engulfing the forest reserve. This could be attributed to the fact that the police force in Uganda has been labeled corrupt; lacks personnel, technical support and capacity to effectively handle environmental crime (Lwasa et al., 2009).

From Table 4, it was clear that the lead agencies were statistically insignificant on their role of enforcement of the environmental/forestry policy at SBCFR, Mayuge district. The local communities engulfing SBCFR therefore, took to lawlessness portrayed by illegalities in the forest reserve with impunity viz., farming, charcoal burning, logging, settlement and the next. NFA the principal lead agency was thus viewed as detractors.

In order to establish the relationship between enforcement activities and compliance with environmental/forestry policy, Table 4 was constructed. The table shows the correlation between the variables in both Enforcement by Lead Agencies and Compliance with environmental/forestry/laws/acts. In this case, the lead agencies, policies, laws and acts represented the government regulatory system while the local communities' responses represented their compliance with enforcement acts as in Table 4.

From Table 5, a Spearman rank correlation was computed to establish the relationship between enforcement and compliance with environmental/forestry laws/acts at SBCFR as $r=0.422$. This value lay on a (0.40-0.59) segment of the strength of a correlation, manifesting a modest/moderate correlation, at a 0.05 level of significance (Mugenda and Mugenda, 2003; Fraenkel and Wallen, 2008). It could therefore, be concluded that there was a modest/moderate relationship between the enforcement activities of the environmental lead agencies and the local communities' compliance with either environmental laws or acts affecting SBCFR, Mayuge district (Table 5).

\section{CONCLUSION}

There was a modest or moderate relationship between the government regulatory system and the local communities' compliance with either environmental laws or acts affecting SBCFR, Mayuge district. This was at $r=0.422$ using Spearman's correlation co efficiency 
analysis. It also be farther portrayed by the fact that lead agencies entrusted with the conservation of SBCFR, Mayuge District were statistically insignificant for they were $>9.21$ at $0.01 \mathrm{df}=2$ as explained. These included the following in order; NFA $\chi^{2}$-calculated (54.6); NEMA (65.4); UWA (76.3); DLC (91.1); DFS (96.3); Police (100.6); ISO (117.4) and UPDF (140.7). This could therefore explain the lawlessness in and around SBCFR, Mayuge district ostensibly backed by politicians.

\section{RECOMMENDATIONS}

NFA, the lead agency charged with the management of the 506 CFR should entrench itself in the effective management. As an autonomous body, NFA should reclaim both its power and authority over the forest reserves from the politicians who contend to have vested interest in these areas. This can be done by following the legal processes, constant seminars and workshops which include the politicians in the light of press. Besides, they should cherish their core values in the management and be allergic to corrupt tendencies leading to overlooking of illegalities in the forest reserves whereby constant lateral transfers of personnel would reduce over familiarity with the locals.

Inter environmental management bodies collaboration should be fully embraced under the stewardship of NEMA with a single goal of clean environment. With collective effort, the local communities engulfing forest reserves would be confronted by different organizations which would lead them into giving up. The research showed that apparently other organizations were reluctant claiming to be ill financed compared to NFA for instance the district forest services; NEMA Officials at the district; the Uganda Police Force and the Production Committee in the District.

General sensitization on forestry resource sustainable use should be embraced by NFA using all medias. This should be after doing a thorough self-appraisals and embracing core values to change NFA's image. The image change may make the body admirable hence internalization of the sensitization message. The media should include among other; radios; televisions; telephone ringtones; news papers; bill boards; school talking compounds; government offices and the next. These should be as consistent and continuous as Christian message which has stayed for $>2000$ years continuously. This continuity needs a government financial hand.

NFA should lobby for financial support from either the government or donations as per the NFPTA 2003 Act for effective management. The money should be used in purchasing and management of tree seedlings; sensitization; equipment acquisition and management of evictions. Resettlement and compensation of encroachers who settled in the forest reserves before 1990 and 1992 as per the international agreements such as the Universal Declaration on Human Rights; International Covenant on Economic, Social and Cultural Rights and the African Commission on Human and Peoples Rights. Those below this period should be given notices and evacuated from the forest reserves. The period accepted for compensation and resettlement is attributed to government's illequipment during the then evictions in the country. Thus, failure to comply should be forcefully evicted; fined, imprisoned or asked to compensate the citizens for denial of ecological benefits they destroyed during their occupation of forest reserve and revoke their land title deeds if any.

\section{REFERENCES}

Amin, E.M., 2005. Social Science Research: Conception, Methodology and Analysis. Makerere University, Kampala, Uganda.

Anonymous, 2007. Kenya nowhere to go: Forced evictions in mau forest. Amnesty International, Centre on Housing Rights and Evictions, Kenya Land Alliance, Hakijamii Trust, Kenya National Commission on Human Rights. Briefing Paper, May 2007.

Aryamanya-Mugisha, H., 1991. The National Environment Action Plan (NEAP) process for Uganda. Focus Environ., 1: 4-8.

Bailey, C.A., 2007. A Guide to Qualitative Field Research. 2nd Edn., Pine Forge Press, London, ISBN: 9781412936507, Pages: 214.

Banana, A.Y., N.D. Vogt, Bahati and G. Ssembajjwe, 2007. Decentralised governance and ecological health: Why local institutions fail to moderate deforestation in Mpigi District of Uganda. Acad. J. Sci. Res. Essay, 2: 434-445.

Bell, J., 1999. How to Complete your Research Project Successfully. UBS Publishers Distributors Ltd., New Delhi, India.

Bikaako-Kajura, W., 2002. Property Rights, Community Participation and Natural Resource Management: The Dynamics of the Tenure Question and Management of Kibale Forest Park. NURRUPublications, Kampala, Uganda.

Bowman, C. and D. Asch, 1992. Strategic Management. Macmillan Education Ltd., London. 
Buyinza, M., 2010. Income distribution analysis of collaborative forest management programme in $\mathrm{Mt}$. Elgon National Park, Uganda: Dual action for poverty alleviation and environment management. Res. J. Applied Sci., 5: 101-107.

Cauvery, R., U.K.S. Nayak, M. Girija and R. Meenakshi, 2007. Research Methodology. S. Chand and Company Ltd., New Delhi, India.

Davenport, T., P. Howard and R. Mathews, 1996. South Busoga forest reserve biodiversity report. Department of Forest, Kampala International University, Uganda.

De Temmerman, E., 2007. 40,000 new encroachers in one year. The New Vision Printing and Publishing Co., Kampala.

Fisher, C., 2007. Researching and Writing a Dissertation: A Guide for Business Students. 2nd Edn., Prentice Hall-Financial Times, Harlow.

Fraenkel, J.R. and N.E. Wallen, 2008. How to Design and Evaluate Research in Education. 7th Edn., McGraw-Hill, Boston, MA, USA., ISBN: 97800735 25969, Pages: 704.

Gay, L.R., G.E. Mills and P. Airasian, 2009. Educational Research: Competencies for Analysis and Applications. 9th Edn., Pearson Education International, New Jersey, USA., Pages: 305.

Hamilton, A.C., 1984. Deforestation in Uganda. Oxford University Press, Nairobi, Kenya

Kothari, C.R., 2004. Research Methodology: Methods and Techniques. 2nd Edn., New Age International Pvt. Ltd. Publishers, New Delhi, India.

Loefler, I., 2000. Lets stop cutting down the government's trees. The East African, January 17-23, 2000, Nairobi, http://www.indexkenya.org/citation.asp?control=A 02481.

Lwasa, S., R. Mwebaza and P.N. Mwanika, 2009. A situation report: The nature and extent of environmental crime in Uganda. Institute of Security Studies, Pretoria, South Africa.

MWLE, 2003. Ministerial policy statement for ministry of water lands and environment vote: 012 , financial year 2003/2004. Presented to Parliament for the Debate of the Revenue and Expenditure 30th June, 2003 Kampala.

Morse, J.M. and L. Richards, 2002. Read Me First for a User's Guide to Qualitative Methods. Sage Publications, New Delhi, India.

Mugenda, O.M. and A.G. Mugenda, 2003. Research methods: Quantitative and qualitative approaches. African Centre for Technology Studies (ACTS), Nairobi, Kenya.
Mugyenyi, O., B. Twesigye and E. Muhereza, 2005. Balancing nature conservation and livelihoods: A legal analysis of the forestry evictions by the National Forestry Authority. ACODE Policy Briefing Paper No. 13, ACODE, Kampala, Uganda.

Mupada, E., 1997. Towards collaborative forest management in the conservation of Uganda's rainforests: A presentation on African rainforests and the conservation of biodiversity. Proceedings of the Limbe Conference, January 17-24, 1997, Earth Watch, Europe Oxford, Limbe, Cameroon.

Mwangi, E., 1998. Colonialism, self-governance and forestry in Kenya: Policy, practice and outcomes. Research in Public Affairs, Working Paper V590.

NEMA, 1999. Constitutional reforms: State of environment report for Uganda. National Environment Management Authority, Kampala, Uganda, pp: 225-228.

NEMA, 2004/5. State of environment report for Uganda 2004/5. National Environment Management Authority, Kampala, Uganda. http:/www.nemaug. org/reports/national_state_report_2004.pdf.

NFA, 2005. Guidelines for successful communication at the national forestry. National Forestry Authority's, Kampala, Uganda.

Nachmias, D. and C. Nachmias, 1987. Research Methods in the Social Sciences. 3rd Edn., St. Martin's Press, New York, USA.

Natusiimira, P., 2007. Imprisioned for Protecting a Forest. National Forestry Authority, Kampala, Uganda.

Nsangi, K.M., 2006. Open Lawlessness intensifies as NFA grapples with encroachers. The Forester News from the Ugandan Forestry Sector, Kampala NFA, Issue No. 15 , pp: 7-8.

Nsita, S.A., 2006. Key issues affecting management of Uganda's forest resources. Proceedings of the Inception Workshop on Forestry organized, June 6-7, 2006, Entebbe, Uganda.

Olet, D.E., 1977. The overall contribution of forestry industries to economic developments of Uganda. M.Sc. Thesis, The University of New Brunswick, Canada.

Oso, W.Y. and D. Onen, 2005. A General Guide to Writing Research Proposal and Report. Option Printers and Publishers, Kisumu, Kenya.

Otieno, A.C. and M. Buyinza, 2010. Collaborative forest management in Uganda: A strategy for controlling deforestation in West Bugwe Forest Reserve, Busia District. Res. J. Applied Sci., 5: 337-344.

Otieno, A.C., 2003. Collaborative forest management: A strategy for controlling deforestation in West Bugwe forest reserve, Busia district. Master's Thesis, Makerere University, Uganda. 
Republic of Uganda, 2001. The Uganda Forestry Policy. Ministry of Water, Lands and Environment, Kampala, Uganda, Pages: 29.

Republic of Uganda, 2002. The National Forest Plan: Ministry of Water, Lands and Environment October 2002. Uganda Forests, Kampala, Uganda.

Republic of Uganda, 2003. The national forestry and tree planting act. Acts Supplement to the Uganda Gazette No. 37, Volume XCVI, UPPC by Order of the Government, Entebbe, Uganda.

Tenywa, G., 2007. Locals Invade South Busoga Forest Reserve. The New Vision Printing and Publishing Co., Kampala, Uganda.
The Republic of Uganda, 1995. The Constitution of the Republic of Uganda 1995. LDC Publishers Printing Press, Kampala, Uganda, Pages: 55.

Tumushabe, G.W. and A. Bainomugisha, 2004. Constitutional reform and environmental legislative representation in Uganda: A case study of Butamira forest reserve in Uganda. ACODE Policy Research Series No. 10, ACODE, Kampala, Uganda. http://pdf.wri.org/acodelegrep.pdf.

Zziwa, A. and D. Waiswa, 2007. Training and Extension: Design of appropriate Agro-Forestry Interventions in Uganda. Makerere University-Fountain Publishers, Kampala, Uganda, pp: 104-119. 